\title{
FIRST DATA ON CETACEAN STRANDINGS AND IN SITU OBSERVATIONS ALONG THE ALGERIAN COAST
}

\author{
Assia Henda-Benrekaa*a, b and Riadh Moulaï ${ }^{b}$
}

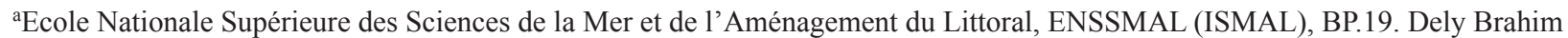
University Campus, 16000 Algiers, Algeria; 'Laboratoire de Zoologie Appliquée et d'Ecophysiologie Animale, Faculté des Sciences de la Nature et de la Vie, Université de Bejaia, Algeria. Email: moulai741@hotmail.com *Corresponding author. Email: henda_assia@yahoo.fr
\end{abstract}

\author{
Article history \\ Received: 4 January 2021; \\ accepted: 29 March 2021

\section{Keywords:} \\ Cetaceans; Algerian coasts; \\ stranding, Delphinidae
}

\begin{abstract}
Data on cetaceans within the pelagic ecosystem remains scarce in the Algerian basin. This is linked to a lack of investigations stemming from the difficulty of quantitative population evaluation through oceanographic surveys and/or strandings statistics. In this context, we considered that it is appropriate to focus on data acquisition from offshore observations as well as setting up a network for monitoring strandings on sites scattered along the Algerian coast. During 10 oceanographic surveys conducted in two Algerian coasts sectors (eastern and central) we observed a total of 245 delphinids corresponding to 8 species that had an irregular distribution. We also identified 83 individuals belonging to five species that stranded between 2007 and 2017.
\end{abstract}

\section{INTRODUCTION}

Cetaceans constitute one of the least-known biological segments of marine biodiversity in Algeria. Very little research has been devoted to them due to the scarcity of systematists, the difficulty of observation and sampling, and considerable human and material resources to be implemented in order to be able to produce a reliable and steady stream of data. Some available data concerning this biological model come from old works (Loche 1840; Doumergue 1920; Lilly 1962, 1964; Lloze 1980) and those of Boutiba (1976, 1989, 1992, 1994a,b, 2003), Boutiba and Abdelghani (1995), Boutiba et al. (1996), and Taleb et al. (1994). This general state is observed throughout the Mediterranean basin. However, on the Algerian coast, the scarcity of data is more obvious. The difficulty is also partly linked to the wandering nature of these species, dispersing across vast distances, thus making statistical analyses rather difficult.

The synthesis done by Boutiba et al. in Grimes et al. (2004) takes stock of the state of knowledge regarding cetaceans on the Algerian coasts. This study makes it clear that most of the data cover the western part of the Algerian coast, with less attention being given to the central and east sectors.

The present study is a starting point for the establishment of an observation and monitoring network capable of providing new and regular data on previously unexplored or poorly studied sectors. It is in this context that we considered it appropriate to focus on acquiring data from offshore observations and setting up a network for monitoring strandings on sites scattered along the Algerian coast.
This strategy aims to: (i) widen the field of investigation, since most of the previous work concerned the western Algerian sector, (ii) improve knowledge of the status of cetaceans in the south-western Mediterranean, and (iii) identify interactions of cetaceans with fishing activities and their habitat.

\section{MATERIALS AND METHODS}

\section{Presentation of the study area}

Our study area covers all the coast of Algeria where three main sectors are delimited: west sector (A) from Telemcen to Ténes, central sector (B) from Ténes to Dellys, and east sector (C) from Dellys to El Taref (Figure 1).

Different ports in each sector have been selected to go out at sea and to conduct in situ cetacean observations. We chose:

Sector A: the Port of Beni-Saf, Ain-Temouchent and the Port of Mostaganem to represent the west sector (Figure 1);

Sector B: the Port of Tamenfoust and the Port of El Djamila in Algiers and the Port of Bouharoun in Tipaza to represent the central sector; and

Sector C: the Port of Boudisand the Port of ZiamaMansouriah in Jijel and the Port of Stora in Skikda to represent the east sector.

Cetacean strandings were investigated only within sector B (Figure 1). 


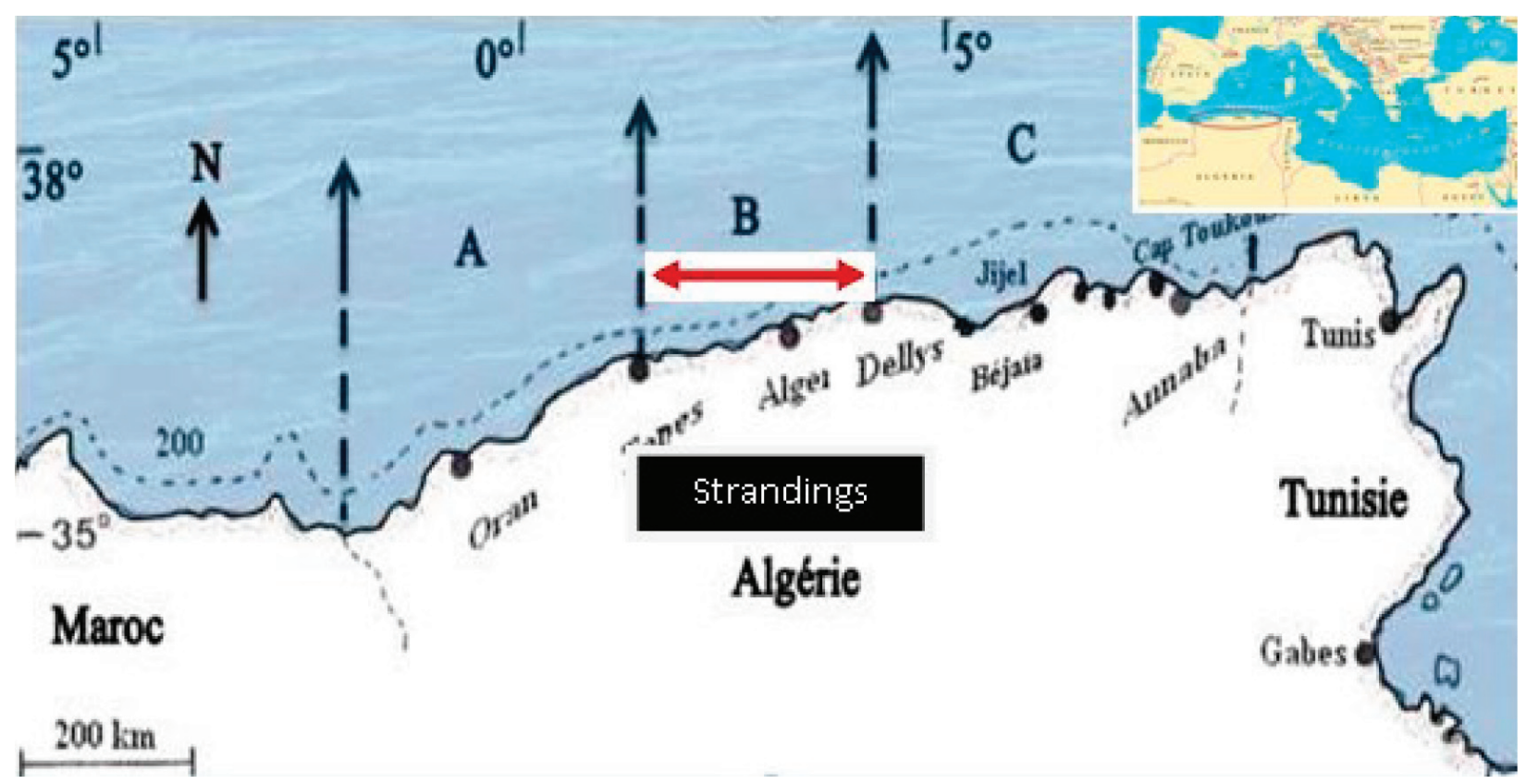

Figure 1. Coastal zone of Algeria and three sectors of cetacean observation.

\section{Monitoring of cetacean strandings and in situ obser- vations}

The monitoring of strandings started in 2006 and was based on a network of observations that we had set up in coordination with a range of institutions (Urban Agency for the Protection and Promotion of the Coastline and Touristic Zones of Algiers(APPL), the National Centre for Research and Documentation for Fishing and Aquaculture, the National High School of Marine Sciences and Coastal Planning, the Coast Guards, Taza National Park in Jijel, the Conservation and Development Unit, and the National Park of Gouraya in Bejaia). This network also provided us data on strandings before 2000 .

The methodological approach developed in this study is classical, and is based on: (1) observations from the mainland, (2) observations related to the economic activity of exploitation (fishing), and lastly (3) in situ observation of living individuals at sea (Gannier 1995):

(1) Observation from the mainland was used mainly for the common dolphin (Delphinus delphis) and bottlenose dolphin (Tursiops truncatus) which are most regularly observed in vivo along the Algerian coasts. These two species are known to be the most coastal (El Bouali 1987; Canadas 2006). This approach makes it possible to provide information on ecology (habitat, depth, frequency, abundance, etc.) and, in the case of strandings, mainly represent information on the mortalities causes that are sought in particular with regard to the quality of the environment (pollution, collisions, and accidental fishing).

(2) The second approach which is related to fishing activities often deals with indirect (accidental) catches which are quite frequent. Tissue and organ samples taken from dead individuals most of the time (livers, muscles, skin, teeth, etc.) provide information on the biology of cetaceans, on their ecology and on population dynamics.

(3) The observation of live cetaceans at sea is based on surveys and/or missions at sea. The surveys are based on observations made by fishermen, recreational boaters, merchant navy vessels and Coast Guards as well as the civil defence. As for the strandings, we proceeded to the diffusion of standardized data sheets (400 copies during the summer period) in order to optimize the cetaceans census. At the same time, more than 20 sea trips along the continental zones were made possible thanks to logistical support from the Taza National Park, the National Navy (Coast Guards), the civil defence and some fishermen and recreational boaters. Our missions at sea took place in calm weather on paths in a straight line between two points of coordinates known preferably by daytime and when the wind was less than or equal to 3 on the Beaufort Wind Scale. The state of the sea had not to exceed stage 3 "slight sea". The wave height had to be less than 1.25 meters so that small species were not underestimated. The prospecting movement speed had to be equal to or greater than 4 knots, with a crew of 3 to 4 persons (Raga 2002; Gannier 1995).

\section{RESULTS}

Stranding monitoring (central sector B, 2007-2017)

Data on strandings in the central Algerian region are presented in Table 1. These data show 83 stranded individuals and 8 cetacean species between 2007 and 2017 . 
Among others, we found Ziphius cavirostris, Grampus griseus, Delphinus delphis and Stenella coeruleoalba (Figure 2).

In the department of Tipaza, it appears that most strandings were concentrated on the coastal line FoukaBouharoun with a maximum of 9 specimens stranded in Bou-Ismail (30\% of strandings). Concerning the species stranded along the Algerian coast, it appears that the majority of strandings were located in the eastern part of the department ( $49 \%$ of strandings) with a very high concentration in the municipality of Ain-Benian, more exactly, at the beach El Djamila (15 stranded individuals) (Figure 3). At Boumerdes, 21\% of the strandings noted were concentrated in the beaches of Dellys.

We note that $50 \%$ of stranding occurred between February and April, the remaining strandings being concentrated during the months from August to NovemberDecember. S. coeruleoalba was the most commonly stranded species, followed by $D$. delphis and Physeter macrocephalus (Table 1).
Table 1. Identification of species and numbers of stranded cetaceans between 2007 and 2017.

\begin{tabular}{|l|c|}
\hline \multicolumn{1}{|c|}{ Species } & $\begin{array}{c}\text { Number of } \\
\text { stranded } \\
\text { specimens }\end{array}$ \\
\hline Stenella coeruleoalba (striped dolphin) & 21 \\
\hline Delphinus delphis (common dolphin) & 11 \\
\hline Physeter macrocephalus (sperm whale) & 9 \\
\hline Tursiops truncatus (bottlenose dolphin) & 9 \\
\hline Globicephala melas (long-finned pilot whale) & 6 \\
\hline Grampus griseus (Risso's dolphin) & 5 \\
\hline Ziphius cavirostris (Cuvier's beaked whale) & 1 \\
\hline Balaenoptera physalus (fin whale) & 2 \\
\hline Unidentified species & 19 \\
\hline Total of stranded individuals & 83 \\
\hline
\end{tabular}

\section{Causes of stranding}

According to our interventions in the field, it turned out that the majority of beached cetaceans were in a state of decomposition (proof of a prolonged stay in the sea before being stranded on the mainland) (Figures 5

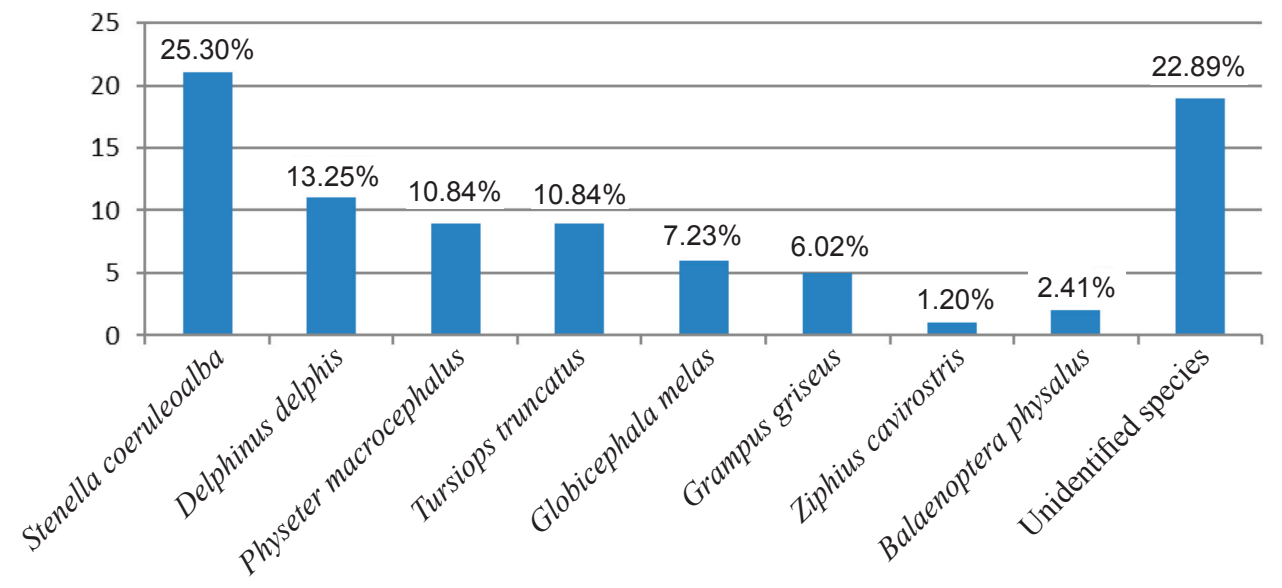

Figure 2. Representation of strandings between 2007 and 2017.

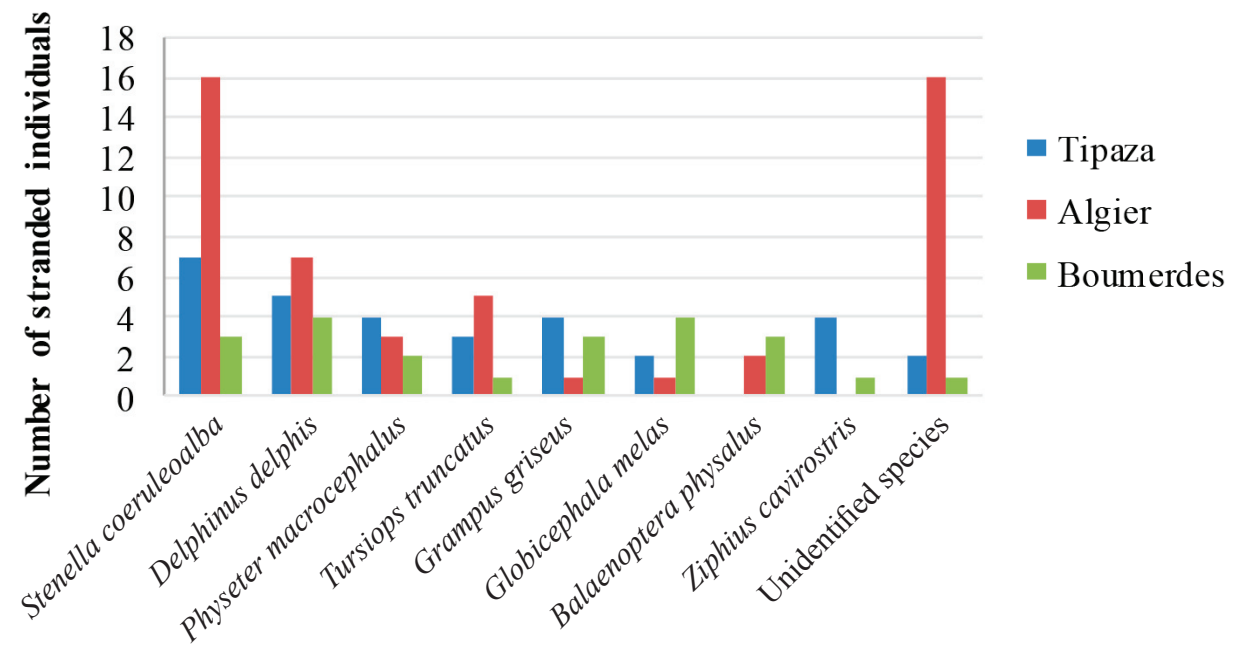

Figure 3. Representation of stranding in central sector between 2007 and 2017. 
and 8). Therefore, the identification of the exact cause of stranding remains unknown. However, $22 \%$ of individuals had severed fins probably related to fishing activity (Figure 9). This interaction is well established, since $13 \%$ of the stranded species presented nets around their body, particularly on the caudal fins. Especially, D. delphis (36\%), P. macrocephalus, T. truncatus (18\%) and G. griseus (18\%) presented severed fins (Figure 6). However, $20 \%$ of the stranded delphinids did not present either wounds or traces of nets on the body, especially young individuals (Figure 4).

Unfortunately, we did not carry out an autopsy on the stranded cetaceans corpses because the stranding surveillance network in the central region is not yet established and we often arrive too late to intervene properly in the field. We also do not have infrastructure for autopsies with qualified veterinarians. It is precisely this work that we wish to do in the near future to establish the exact causes of strandings in the Algerian central sector.

\section{Cetacean observations in situ}

From March to August 2015, ten offshore explorations were conducted which resulted in a census of a total of 245 delphinids off the Algerian coast: 59 individuals were observed off the western coast (sector A, 22.86\%), 88 individuals on the central coast (sector B, 35.92\%) and 98 individuals on the eastern coast (sector C, $40 \%$ ). On the eastern coast, the majority of the species encountered were found in the region of Jijel, mainly in Cavallo (Figure 9).

A total of 155 D. delphis were observed, representing $63 \%$ of appearance frequencies. In view of our observations, it should be noted that there is no preferred observation zone for this species. Nevertheless, in terms of abundance, it is necessary to emphasize preponderance in the western sector, especially between Ain Tagourait and Cherchell. Next to D. delphis, we counted 52 individuals of $T$. truncatus ( $21 \%$ of the encountered delphinids) (Figure 10).

$S$. coeruleoalba was also present and very often mixed with $D$. delphis, but its population was much smaller, a total of 11 appearances $(8 \%)$. Moreover, we have

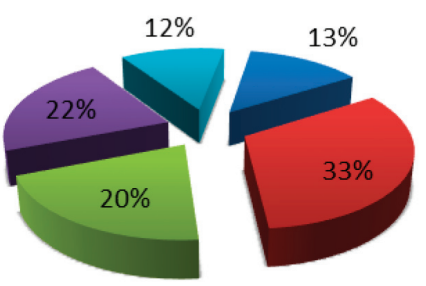

presence of traces of
nets on the body
Decomposition state
Intact body
cut
unknown reasons

Figure 4. Representation of the physical state of the corpses of cetaceans stranded between 2007 and 2017.

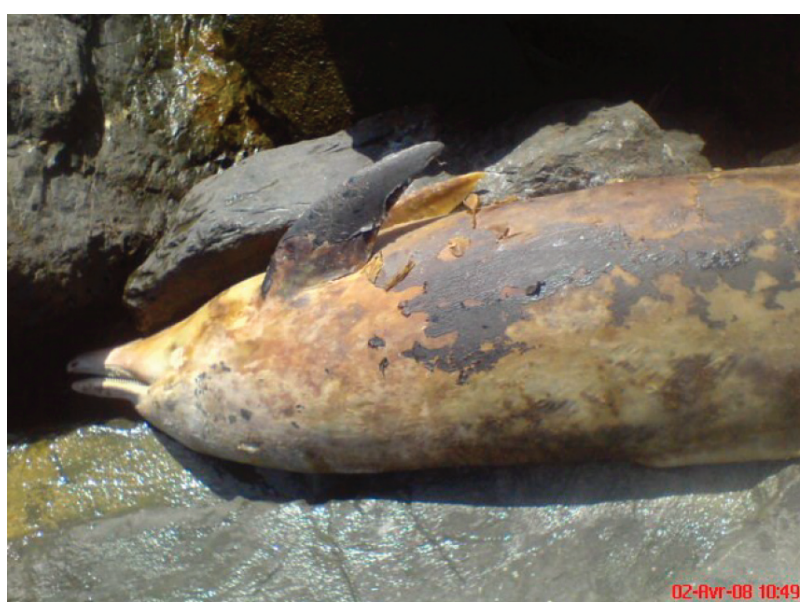

Figure 5. Stranding of a delphinid in a state of decomposition in April 2008 in Bou Ismail (west Algiers).

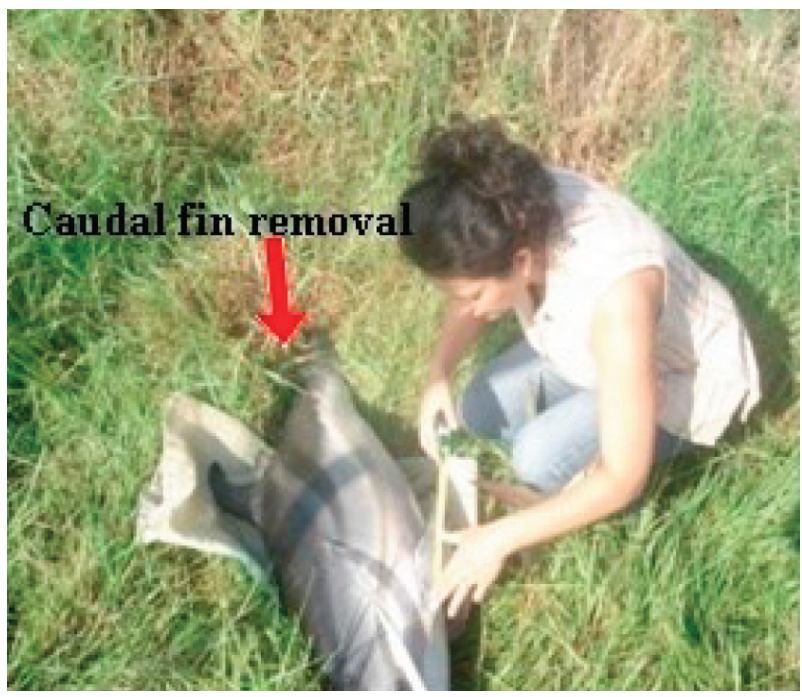

Figure 6. Intervention during the stranding of a young Stenella coeruleoalba in August 2009 at the beach broken boat in Bordj el Kiffan (east Algiers).

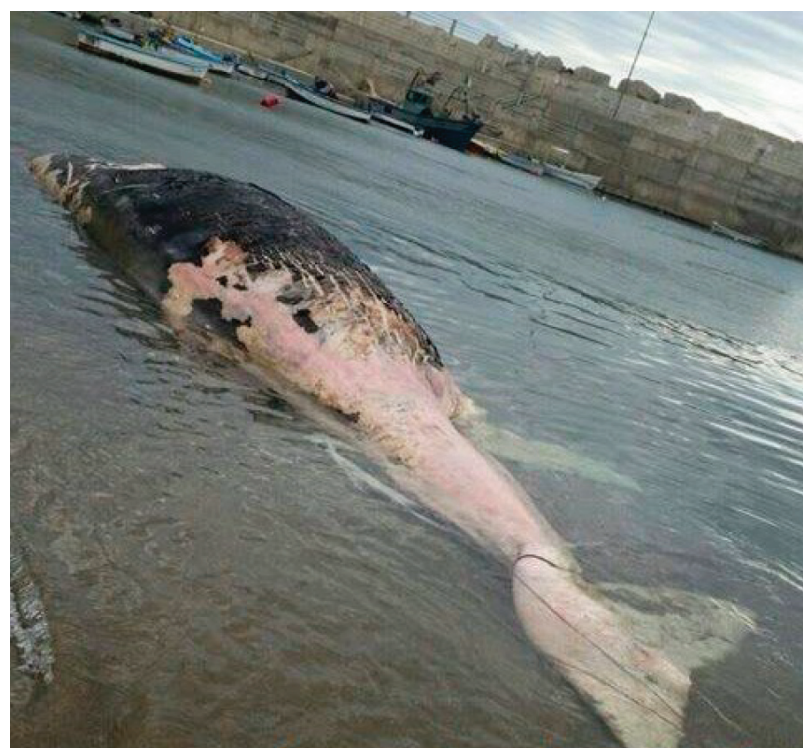

Figure 7. Stranding of a Physeter macrocephalus at the Franco beach of Raïs Hamidou in May 2017 (Algiers). 
noted the presence of Physeteridae off the Algerian Note also that no cetacean sightings have been made off basin coast. Three sperm whale individuals were listed the bay of Algiers. However, all observations made in during the study period, which represents $2 \%$ of all this area begin either east of the bay from Cape Matifou encounters (Figure 10). or west from Cape Acrata.

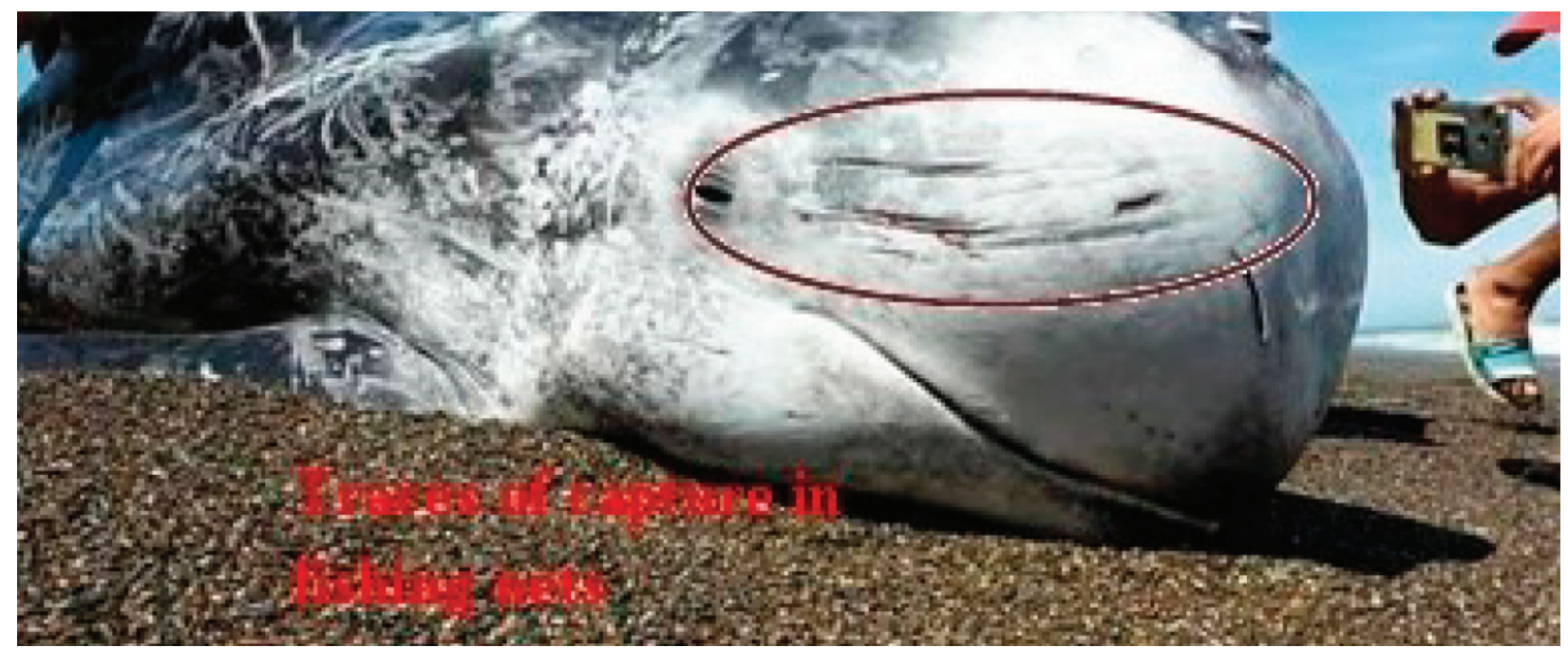

Figure 8. Grounding of a Grampus griseus on Sidi El Djilali (Tipaza) beach in September 2017.

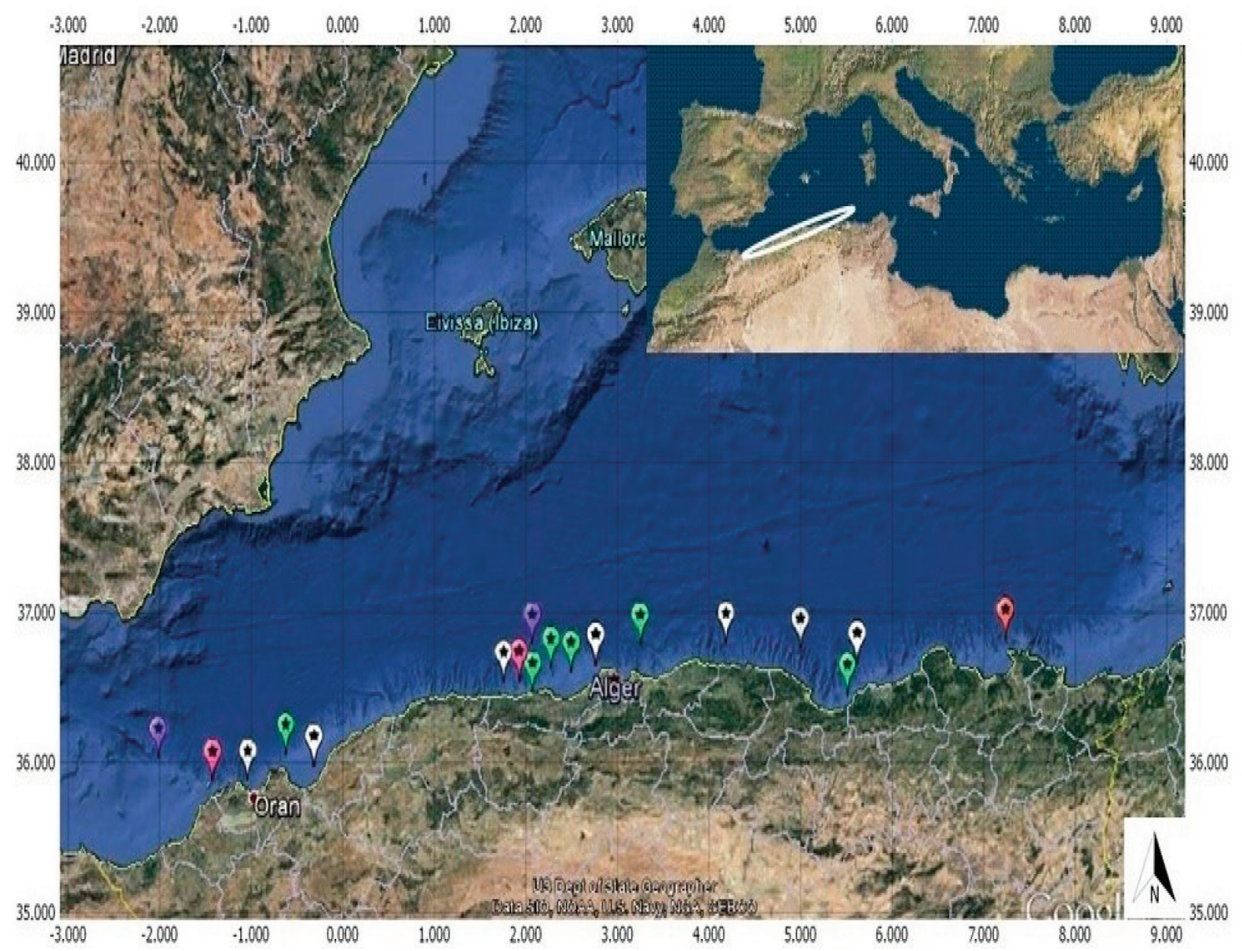

(ึ) Delphinus delphis

Ptenella coeruleoalba

Physeter macrocephalus

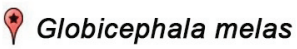

$\stackrel{7}{*}$ Tursiops truncatus

Figure 9. Geographic distribution of cetaceans along the Algerian coast during the summer season 2015.

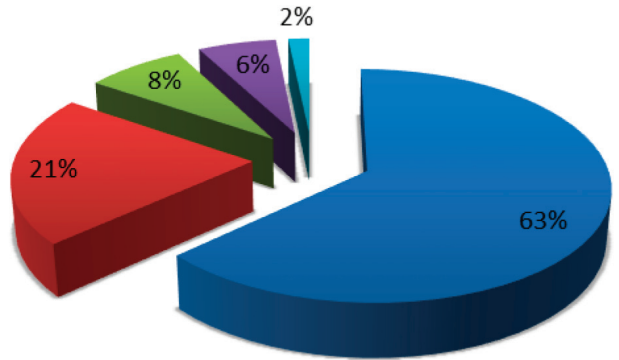

- Delphinus delphis

- Tursiops truncatus

- Stenella coeruleoalba

- Globicephala melas

- Physeter macrocephalus

Figure 10. Frequency of species observed in situ along the Algerian coast in 2015. 


\section{DISCUSSION}

Regarding the previous observations made along the central and eastern Algerian coast, Mechenene (2007) affirms that the common dolphin is the most frequently observed, that is to say it makes $77.77 \%$ of the total of encounters on the western part of the golf of Bejaia. Henda and Boutiba (2007) found that $S$. coeruleoalba is also present and is often found in a mixed group with D. delphis $(20.37 \%$ in the Bejaia region and $12 \%$ on the Algiers coasts). They also counted 36 T. truncatus (23\% of the total population) during the same period, with a preferential distribution for the eastern coast near the Algiers basin (Jijel and Skikda).

If we compare with studies of Boutiba (1994), he confirms that from 1975 to $1990 \mathrm{D}$. delphis was the most common species on the western coast with a high density (103 D. delphis listed individuals and 46 S. coeruleoalba), especially on Oran coasts (frequency of $74.2 \%$ for D. delphis). The same emerges from our study, because D. delphis is observed with a frequency of $63 \%$. However, Terkmani (2011) after six months of exploration found that it is rather T. truncatus that is most frequently observed with $94.63 \%$ of observation frequency.

With regard to our observations, T. truncatus is the second most frequent species. Larbi Doukara (2015) who conducted a 14 days summer survey off the Oran region noted the presence of a mixed group of $10 \mathrm{D}$. delphis and blue and white dolphin, two T. truncatus and some individuals of G. griseus and G. melas. Henda and Boutiba (2007) noted a unique sighting of this species off eastern waters, particularly in the Cap de Fer region.

Off the coast of Tunisia, T. truncatus and S. coeruleoalba were the most common species followed in decrease of occurrence by $B$. physalus, $Z$. cavirostris and P. macrocephalus (Aïssi et al. 2015). In Morocco, common and striped dolphins were seen together on 18 occasions. Pilot whales were seen together with sperm whales on five occasions and with bottlenose dolphins on 14 occasions (De Stephanis 2008).

In our study, it would be difficult, if not premature, to draw definitive conclusions from the data presented for in situ observations. With regard to strandings, it is possible to consider that more than $90 \%$ of strandings have not escaped the report, especially since the establishment of our observation network. The essential reasons that justify our cautiousness with respect to the results of in situ observations are as follows:

(i) duration of observation, which is still limited and does not cover all seasons;

(ii) weather conditions: bad weather sometimes cancels for weeks the missions at sea and the follow-up of observations is compromised;

(iii) the fact that the covered area can be enlarged substantially if appropriate and required means are used, making it possible to multiply the chances of encountering cetaceans at sea.

Nevertheless, with regard to the data presented above it is possible to affirm the following. There are no preferred stranding areas in the sectors of study or preferential species in terms of frequency. This is especially true in the central sector, because in the region of Bejaia it is almost exclusively $D$. delphis that stranded. On the other hand, in terms of abundance it is obvious that the common dolphin is most exposed to strandings. A comparison can be made with a study in Tunisia in 2018 where it was rather $T$. truncatus that stranded most frequently, followed by $B$. physalus (Attia Elhili et al. 2018). According to Masski and De Stephanis (2015), in Morocco it is Delphinidae that stranded the most (42\%) along the Moroccan coasts between 1980 and 2009 , with $S$. coerulloalba in the first position followed by $D$. delphis.

It is also interesting to note that $50 \%$ of strandings in the Algiers sector were between the months of February and April; the rest were concentrated during the months of August and November-December. In the east, most of the strandings occurred during spring.

It should be noted that almost all individuals of stranded cetaceans have traces (mutilations) of fishing nets. These injuries are apparent either on the belly, on the head, on the caudal fin or the pectoral fin. Sometimes one of these fins is severed. In any case, more than $90 \%$ of strandings in which we personally assisted concern individuals in the state of more or less advanced putrefaction.

With regard to in situ observations, it can be said that privileged areas are highlighted both in the centre and in the east. In addition, between $75 \%$ and $90 \%$ of frequencies and abundances are attributable to D. delphis. Mixed groups are often observed, mainly among $S$. coeruleoalba and common dolphins. The cetaceans observed during the study period are most often in small groups (2 to 4 individuals). Sometimes, they are observed in groups of more than 10 individuals in relatively limited perimeters.

Finally, it should be noted that among the major handicaps when observations are pursued at sea and when a consistent database is established, human and material resources are the most important element. The densification of our observation network depends in part on awareness with respect to the cetaceans issue as a whole not only among the fishing community but also among the recreational community and at the university level. 


\section{ACKNOWLEDGEMENTS}

We would like to thank the Directorate General for Scientific Research and Technological Development, DGRSDT (MESRS) for its support.

\section{REFERENCES}

Aïssi, M., A. Arcangeli, R. Crosti, M. N. Daly Yahia, B. Loussaief, A. Moulins, G. Pellegrino, M. Rosso, L. M. Tringali, and P. Tepsich. 2015. Cetacean occurrence and spatial distribution in the central Mediterranean Sea using ferries as platform of observation. Russian Journal of Marine Biology 41: 343-350. https://doi.org/10.1134/S1063074015050028

Attia ElHili, H., C. Bensalah, H. Boubaker And, and W. Ayari. 2018. Bulletin de l'institutnationaldes sciences et technologies de la mer de salammbô [Bulletin of the National Institute of Science and Technology of the Salammbô Sea] 45: 39-42. Numéro spécial [Special number]. ISSN 0330-0080.

Boutiba, Z. 1976. Etudes ostéographique setostéoloiques de trois specimens d'Odotoncètesé chouéssur la côte Oranaise (D. delphis, T. truncatus, G. melaena). D. E. S., univ.d'Oran, Alger [Osteographic and osteological studies of three specimens of Odotoncetes stranded on the Oran coast (D. delphis, T. truncatus, G. melaena). D. E. S., Oran University, Algiers, 60 pp]

Boutiba, Z. 1989. Répartitionet fréquences des échouages des cétacéssur le littoral Ouestalgérien. Communication présentée au séminaire national sur les sciences et Technologie de la mer, Alger, février 1989. Alger, 8 pp. [Distribution and frequencies of cetacean strandings on the West Algerian coast. Communication presented at the national seminar on marine science and technology, Algiers, February 1989, 8 pp.]

Boutiba, Z. 1992. Les mammifères marins d'Algérie. Statut, répartition, biologie, etécologie. Thèse Doct. Etat, univ. Esenia Oran, 575 pp. [Marine mammals of Algeria. Status, distribution, biology, and ecology. PhD thesis. State, univ. Esenia Oran, 575 pp.]

Boutiba, Z. 1994a. Etudes comparatives des échouageset des observations en mer des petits delphinidés sur les côtes nord et sud de la Méditerranée occidental. Actes de la 3éme Conférence internationale pour la protection des Mammifères marins en Méditerranée occidentale (RIMMO), 37-40 pp. [Comparative studies of strandings and observations at sea of small delphinids on the north and south coasts of the western Mediterranean. Proceedings of the 3rd International Conference for the Protection of Marine Mammals in the Western Mediterranean (RIMMO), 37-40 pp.]

Boutiba, Z. 1994b. Bilan de nos connaissances sur la présence des Cétacés le long des côtes Algériennes. [As- sessment of our knowledge on the presence of cetaceans along the Algerian coasts] Mammalia 58 (4): 613-622. https//doi.org/10.1515/mamm.1994.58.4.613

Boutiba, Z. 2003. Dauphins et Baleines d'Algérie. [Dolphins and Whales of Algeria]. Edited by Dar El Gharb, $107 \mathrm{pp}$.

Boutiba, Z., and F. Abdelghani.1995. Food of the Common Dolphin (Delphinus delphis, L.) in Algerian waters. In European Cetacean Society - 9 th conference, Lugano (Switzerland) 19-11 February 1995, edited by P. G. H. Evans and H. Nice, 2-4 pp.

Boutiba, Z., D. Hammouten, D. Merzoug, M. Bouderbala, M. Z. Taleb, and F. Abdelghani. 1996. Le roqual commun (Balenoptera physalus)dans le bassin sud de la Méditerranée occidentale. Etat actuel des observations. Actes RIMMO 5: 24-25. Antibes (France). [Roqual common (Balenoptera physalus) in the southern basin of the western Mediterranean. Current state of sightings. RIMMO Acts] 5: 24-25. Antibes (France).

Canadas, A. 2006. Towards conservation of dolphins in the Alboran sea. PHD Thesis, University Autonoma de Madrid, 351 pp. URI:http://hdl.handle.net/10486/663671

De Stephanis, R., T. Cornulier, P. Verborgh, J. Salazar Sierra, N. Pérez Gimeno, and C. Guinet. 2008. Summer spatial distribution of cetaceans in the Strait of Gibraltar in relation to the oceanographic context. Marine Ecology Progress series mar ecol prog ser 353: 275-288.doi: 10.3354/meps07164

Doumergue, F. 1920. Note surun dauphin globicephale capture dans les eaux d'Ain Turk (Prés d'oran). Bull. Trim. Soc. Geogr. Et Archéol. d'Oran. [Note on a pilot whale dolphin caught in the waters of Ain Turk. Bull. Trim. Soc. Geogr. and Archéol. from Oran Sept.: 62-74.]

El Bouali, M. 1987. Les cétacés du littoral Ouest Algérien. E. S., Univ. d'Oran Alg., [Cetaceans of the West Algerian coast. E. S., Univ. Oran Alg., 62 pp.]

Gannier, A. 1995. Les cétacés de Méditerranée NordOccidentale: estimation de leurabondanceetmise en relation de la variation saisonnière de leur distribution avec l'écologie du milieu. Thèse de doctorat. Sciences de la vie et de la terre. [Cetaceans of the North-Western Mediterranean: estimation of their abundance and correlation of the seasonal variation of their distribution with the ecology of the environment. Doctoral thesis. Life and earth sciences.] Ecole Pratique des Hautesétudes. Montpellier, 438 pp. http://www.sudoc.fr/005459052

Grimes, S., Z. Boutiba, A. Bakalem, M. Bouderbala, B. Boudjellal, S. Boumaza, M. Boutiba, A. Guedioura, A. Hafferssas, F. Hemida, N. Kaïdi, F. Kerzabi, H. Khelifi, A. Merzoug, A. Nouar, B. Sellali, H. SellaliMerabtine, R. Semroud, H. Seridi, M. Z. Taleband, and T. Touahria. 2004. Biodiversité marine etlittorale Algérienne. Projet Sonatrach/LRSE, edited by Diwan Alger; Sonatrach [Algerian marine and coastal biodiversity. Projet Sonatrach / LRSE, edited by Diwan Alger; 
Sonatrach], 362 pp. http://www.sudoc.fr/114282102

Henda, A., and Z. Boutiba. 2007. Observations In situeté chouagesrécents des cétacés dans le secteurcentre et Est de la côteAlgérienne. Workshop international. Biodiversitéet ecosystems littoraux BEL01, 27-29 November 2007 Oran [Recent observations of cetaceans in situ in the central and eastern sector of the Algerian coast. International workshop. Biodiversity and coastal ecosystems BEL01, 27-29 November 2007 Oran, 2 pp.]

Larbi Doukara, K. 2015.Etat de la conservation etévolution de la population des petitsdelphinidés: Grand dauphin Tursiops truncatus et Dauphin commun Delphinus delphis dans le littoral occidental Algérien. Thèse Doc. d'Etat, University Oran [State of conservation and evolution of the population of small delphinids: Bottlenose dolphin Tursiops truncatus and Common dolphin Delphinus delphis in the western Algerian coast. State Doc Thesis, Oran University, 303 pp.]

Lilly, J. C. 1962. L'hommeet le dauphin [The man and the dolphin]. Stocks, Paris, Fr., 157 pp.

Lilly, J. C. 1964. Animal in aquatic environments: adaptation of mammals to the ocean. Handbook of physiology, Amer. Physiol. Sec.: 741-747. Washington, USA.

Lloze, R. 1980. Les échouages des cétacéssur la côteOranaise [The man and the dolphin]. Bull. Soc. Géogr. Et Archéol. D'Oran: 47-50.

Loche, V. 1840. Exploration scientifique de l'Algérie (Histoire des mammifères marins) [Scientific exploration of Algeria (History of marine mammals)]. Paris, A. Bertrand, 1867, 123 pp. http://www.sudoc.fr/017731402
Masski, H., and R. DeStephanis. 2015. Cetaceans of the Morocan coast: Information from a reconstructed stranding database. Journal of the Marine Biological Association of the United Kingdom:1-9. DOI: 10.1017/ S0025315415001563

Mechenene, L. 2007. Etude des Cétacés du golf de la région de Bejaia. Mémoire [Study of cetaceans in the golf course of the Bejaia region.] (D. E. U. A) ENSSMAL, $52 \mathrm{pp}$.

Raga, J. A. 2002. Projet d'établissement d'un réseaurégional pour l'échouage des cétacés en Méditerranée et dans la Mer Noire. Rapport Secrétariat d'ACCOBAMS 28 février 2002, Monaco. Document MOP1 /inf. [Project for the Establishment of a Regional Network for the Stranding of Cetaceans in the Mediterranean and the Black Sea. ACCOBAMS Secretariat Report February 28, 2002, Monaco. Document MOP1 / inf. 7, 14 pp.]

Taleb, M. Z., M. Bouderbala, and Z. Boutiba. 1994. Corrélation entre les échouages de cétacéset la vitesse des vents au niveau du littoral Ouest Algérien. Actes Rimmo 5: 7. Antibes (France) [Correlation between cetacean strandings and wind speed at the level of the West Algerian coast. Actes Rimmo 5: 7. Antibes (France).]

Terkmani, F. 2011. Estimation de l'abondance des Delphinisés le long du littoral occidental Algérien.Thèse de Magister, Université d'Oran, Algérie [Estimation of the abundance of the Delphinized along the western Algerian coast. Magister's thesis, University of Oran, Algeria, 175 pp.] 